with premature labour without affecting urinary potassium excretion. Standard doses by mouth and via aerosol have no appreciable effect on plasma potassium concentrations. Inhalation of salbutamol is effective, however, in reducing exercise-induced hyperkalaemia and as prophylaxis against hyperkalaemic familial periodic paralysis.

In the present case there was no history of diuretic treatment, vomiting, or diarrhoea and no other cause of hypokalaemia could be identified. Renal mechanisms are unlikely to have played a part as neither plasma aldosterone concentration nor urinary potassium excretion was raised. The low aldosterone concentration may have resulted from a direct inhibitory effect of hypokalaemia on the zona glomerulosa cells combined with a low level of circulating renin. This low plasma renin activity may have resulted from an inhibitory adrenergic mechanism; a reduced renin response to tilting has been shown after salbutamol in man. ${ }^{4}$

Hypokalaemia is a potentially serious consequence of adrenergic agonist overdosage. Propranolol, a non-selective beta-blocker, prevents tachycardia and hypokalaemia induced by intravenous salbutamol $^{5}$ and thus would seem to be an appropriate form of treatment.

${ }^{1}$ Morrison GW, Farebrother FW. Overdose of salbutamol. Lancet 1973; ii:681.

2 Clausen T, Flatman JA. The effect of catecholamines on Na-K transport and membrane potential in rat soleus muscle. $\mathcal{F}$ Physiol (Lond) 1977; 270:383-414.

${ }^{3}$ Gungdogdu AS, Brown PM, Juul S, Sachs L, Sonksen PH. Comparison of the hormonal and metabolic effects of salbutamol infusion in normal subjects and in insulin-requiring diabetics. Lancet 1979 ;ii :1317-21.

4 Wiggins R, Davies R, Basar I, Slater JHD. The inhibition of adrenergically provoked renin release by salbutamol in man. $\mathrm{Br} f \mathrm{Clin}$ Pharmacol $1978 ; 5: 213-5$.

${ }^{5}$ Berend N, Marlin GE. Characterization of the $\beta$ adrenoceptor subtype mediating the metabolic actions of salbutamol. Br $\mathcal{F}$ Clin Pharmacol $1978 ; 5: 207-11$.

(Accepted 29 fanuary 1981)

Department of Medicine, Bristol Royal Infirmary, Bristol BS2 8HW I A D O'BRIEN, MB, MRCP, research registrar J FITZGERALD-FRASER, MB, MRCP, senior house officer I G LEWIN, MB, MRCP, senior registrar

R J M CORRALL, MD, MRCP, consultant physician

\section{Interaction of ethinyloestradiol with ascorbic acid in man}

Ethinyloestradiol is the oestrogen most often present in combined oral contraceptive steroid preparations. We have shown that this steroid has a mean bioavailability of only $40 \%{ }^{1}$ owing to extensive first-pass metabolism. A large proportion of this first-pass metabolism occurs in the gut wall during absorption with the formation of a sulphate conjugate. ${ }^{2}$ Sulphate conjugation of other drugs such as paracetamol is inhibited by ascorbic acid, ${ }^{3}$ a drug that also undergoes sulphate conjugation in the gut wall. In a preliminary study four out of six women showed an increase in plasma ethinyloestradiol concentrations when a single dose of ethinyloestradiol was administered with ascorbic acid. ${ }^{4}$ We therefore studied the effect of ascorbic acid in women receiving long-term treatment with oral contraceptive steroids.

\section{Patients, methods, and results}

We studied five female volunteers aged between 22 and 33 years who were taking oral contraceptive preparations containing $30 \mu \mathrm{g}$ of ethinyloestradiol (Ovranette in two, Eugynon 30 in three). Written informed consent was obtained from each volunteer and approval for the study given by the Mersey regional ethical committee.

The volunteers were studied in two consecutive menstrual cycles during the last week of oral contraceptive administration. In random order one of these weeks served as a control and in the other the contraceptive preparation was given with a $1 \mathrm{~g}$ dose of effervescent ascorbic acid (Ascorbef, CoxContinental Ltd). Blood samples $(10 \mathrm{ml})$ were obtained six and 24 hours after the oral contraceptive preparation had been taken on three consecutive days at the same stage in each cycle. The plasma was separated by centrifugation and stored at $-20^{\circ} \mathrm{C}$ until analysis for its ethinyloestradiol content by a sensitive radioimmunoassay. ${ }^{1}$ Statistical analysis was by Student's $t$ test for paired samples.

The table shows the mean of the three plasma ethinyloestradiol concentrations obtained in each volunteer in each study period six and 24 hours after dosing. During treatment with ascorbic acid the mean concentrations were raised at six and 24 hours in all patients, and this difference was statistically

Mean ( $t S E$ ) plasma ethinyloestradiol concentrations ( $n g / l)$ six and 24 hours after a $30 \mu \mathrm{g}$ dose of ethinyloestradiol with and without ascorbic acid. Each value is the mean of samples taken on three consecutive days

\begin{tabular}{|c|c|c|c|c|c|c|}
\hline \multirow[b]{2}{*}{$\begin{array}{l}\text { Case } \\
\text { No }\end{array}$} & \multicolumn{3}{|c|}{ Six hours } & \multicolumn{3}{|c|}{24 hours } \\
\hline & Control & $\begin{array}{l}\text { With } \\
\text { ascorbic } \\
\text { acid }\end{array}$ & $\begin{array}{c}\% \\
\text { increase }\end{array}$ & Control & $\begin{array}{l}\text { With } \\
\text { ascorbic } \\
\text { acid }\end{array}$ & $\begin{array}{c}\% \\
\text { increase }\end{array}$ \\
\hline $\begin{array}{l}1 \\
2 \\
3 \\
4 \\
5\end{array}$ & $\begin{array}{l}60+5 \\
85+5 \\
20+3 \\
42+2 \\
37+6\end{array}$ & $\begin{array}{l}70+4 \\
95+6 \\
24 \div 3 \\
53+7 \\
41+3\end{array}$ & $\begin{array}{l}16 \cdot 7 \\
11 \cdot 8 \\
20 \cdot 0 \\
26 \cdot 2 \\
10 \cdot 8\end{array}$ & $\begin{array}{r}27+2 \\
34+5 \\
4+1 \\
27+7 \\
12+2\end{array}$ & $\begin{array}{r:l}43 & 6 \\
56 & +7 \\
8 & 2 \\
33 & 5 \\
16 & +5\end{array}$ & $\begin{array}{c}59 \cdot 3 \\
64 \cdot 7 \\
100 \\
22 \cdot 2 \\
33 \cdot 3\end{array}$ \\
\hline $\begin{array}{l}\text { Mean } \\
\text { Significance }\end{array}$ & $49 \pm 11$ & $57 \pm 12$ & $16 \cdot 3$ & $\begin{array}{r}21 \pm 5 \\
p\end{array}$ & $31 \pm 9$ & $47 \cdot 6$ \\
\hline
\end{tabular}

significant. The table also shows the percentage increases in the concentrations. The mean concentrations for the group as a whole were raised at six hours from $49 \mathrm{ng} / \mathrm{l}$ to $57 \mathrm{ng} / \mathrm{l}$, an increase of $16.3 \%$, and at 24 hours from $21 \mathrm{ng} / \mathrm{l}$ to $31 \mathrm{ng} / \mathrm{l}$, an increase of $47.6 \%$. No adverse effects were experienced by the volunteers throughout the study.

\section{Comment}

Concurrent administration of ascorbic acid with combined ora contraceptive steroid preparations clearly causes the plasma concentration of ethinyloestradiol to rise. The dose of ascorbic acid used is one that is often taken to prevent the common cold. The increased concentrations at six hours might be due to an interaction in the intestinal mucosa, since the ability to produce sulphate conjugates may be swamped by a $1 \mathrm{~g}$ dose of ascorbic acid. This would reduce the first pass effect of ethinyloestradiol, thus increasing its systemic bioavailability and plasma concentration. The plasma concentrations of ethinyloestradiol 24 hours after dosing were increased by $47.6 \%$, rather more than the increase seen at six hours, which may be due to the reduced conjugation of ethinyloestradiol that is absorbed after enterohepatic circulation. ${ }^{1}$

The increase in plasma concentrations of ethinyloestradiol during treatment with ascorbic acid might be of some benefit in permitting wider use of the very-low-dose ethinyloestradiol preparations. Ascorbic acid at this dose level is generally free of side effects. ${ }^{5}$

We thank the Medical Research Council, the World Health Organisation, the Wellcome Trust, the Mersey Regional Health Authority, the Peel Medical Trust, Schering AG, and Wyeth Pharmaceuticals for financial help.

1 Back DJ, Breckenridge AM, Crawford FE, et al. An investigation of the pharmacokinetics of ethynylestradiol in women using radioimmunoassay. Contraception 1979;20:263-73.

2 Back DJ, Bates M, Breckenridge AM, et al. The in vitro metabolism of ethinyloestradiol, levonorgestrel and mestranol by human jejunal mucosa. Br f Clin Pharmacol 1980;9:281-2P.

${ }^{3}$ Houston BJ, Levy G. Drug biotransformation interactions in man. VI. Acetaminophen and ascorbic acid. F Pharm Sci 1976;65:1218-21.

4 Back DJ, Bates M, Breckenridge AM, et al. Drug metabolism by gastrointestinal mucosa-clinical aspects. In: Prescott LF, Nimmo WS, eds. Drug absorption. Australasia: ADIS Press, 1980:80-7.

${ }^{5}$ Briggs MH, Garcia-Webb P, Johnson J. Dangers of excess vitamin C. Med f A A ust 1973;2:48-9.

(Accepted 25 February 1981)

Department of Pharmacology and Therapeutics, University of Liverpool, Liverpool L69 $3 \mathrm{BX}$

D J BACK, BSC, PHD, lecturer in pharmacology

A M BRECKENRIDGE, MD, FRCP, professor of clinical pharmacology

M MACIVER, MD, MRCP, Wellcome research fellow in clinical pharmacology (now senior medical registrar, Clatterbridge Hospital, Bebington, Merseyside)

M L'E ORME, MD, FRCP, senior lecturer in clinical pharmacology

H PURBA, BSC, technician

P H ROWE, MSC, PHD, research fellow 